\title{
CHECK-LIST OF SASKATCHEWAN MOTHS PART 9: \\ QUAKERS AND BORERS
}

RONALD R. HOOPER, Saskatchewan Museum of Natural History, 2340 Albert Street, Regina, Saskatchewan. S4P 3V7

Abbreviations used: $\mathrm{s}=$ south, $\mathrm{n}=$ north, $\mathrm{w}=$ west, e = east, $\mathrm{CNC}=$ the only known Saskatchewan records of the species that we know of are in the Canadian National Collection in Ottawa. (Unless otherwise indicated all the species are represented in the collection of the Saskatchewan Museum of Natural History, Regina.)

\section{Quaker and Borer Moths}

\section{(Amphipyrinae)}

These are medium-sized Owlet Moths with rather long abdomens that usually extend about half the width of the hind wing beyond the lower edge of the wing on a mounted specimen. The eyes are bald and have no lashes. The hind tibiae have no spines. In some genera the lar- vae are surface or underground cutworms, but in the Borer Moths the larvae live in the stems of plants.

Mullein Quaker - Apamea verbascoides (Gn.) - Reported for Saskatchewan by W. Forbes of Cornell University.

Wood-coloured Quaker - Apamea lignicolora (Gn.) - s Sask. $\mathrm{n}$ to Aylsham.

Brown-banded Quaker - Apamea auranticolor (Grt.) - Saskatoon (in the collection of the National Research Council).

Airy Quaker - Apamea vultuosa (Grt.) Tantallon and Fort Qu'Appelle.

Dusky Quaker - Apamea plutonia (Grt.) 


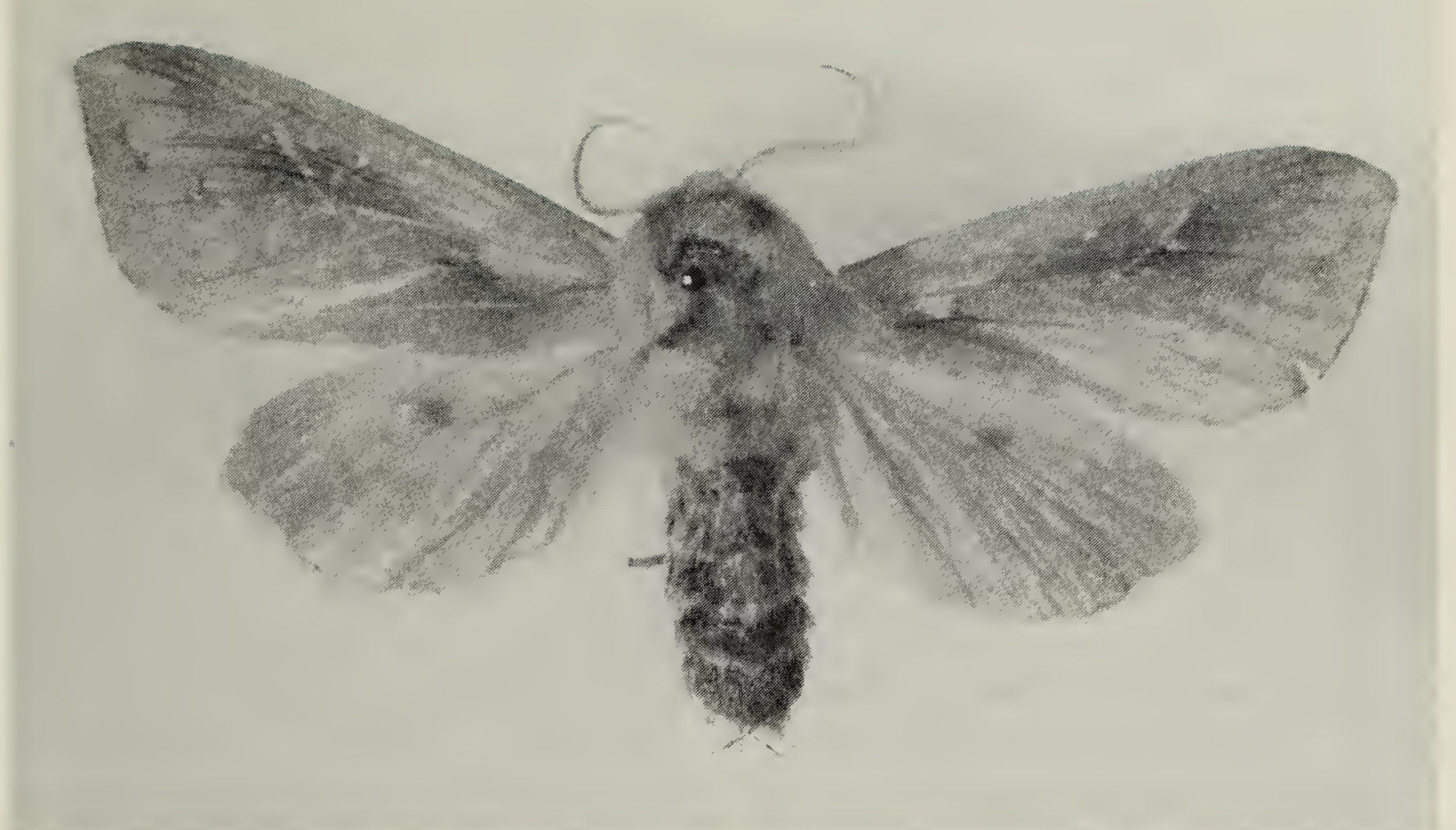

- $s$ Sask. $n$ to Shoal Lake and Onion Lake.

Northern Quaker - Apamea amputatrix (Fitch) - s Sask. n to Creighton and La Ronge.

Dewy Quaker - Apamea alia (Gn.) - s Sask. $\mathrm{n}$ to Aylsham.

Montana Quaker - Apamea inordinata (Morr.) - s Sask. $n$ to Halbrite and Old Wives Lake.

Spalding's Quaker - Apamea spadlingi (Sm.) - Saskatoon (in the collection of the National Research Council).

Grey Quaker - Apamea cinefacta (Grt.) - s Sask. $n$ to Aylsham.

Parcata Quaker - Apamea parcata (Sm.) - s Sask. n to Punnichy.

Southern Quaker - Apamea impulsa (Gn.) - Shoal Lake and Cumberland House.

Broken-banded Quaker - Apamea indocilis (Wlk.) - Red Earth; - Apamea indocilis runata $(\mathrm{Sm}$.) - Halbrite.

Pale-banded Quaker - Apamea finitima (Gn.) - s Sask. n to Aylsham.

Red-winged Quaker - Agroperina lateritia (Hufn.) - s Sask. n to Aylsham.
Ruby Quaker - Agroperina dubitans (Wlk.) - s Sask. n to Deschambault Lake and La Ronge.

Inficita Quaker - Agroperina inficita (Wlk.) - throughout Saskatchewan.

Lined Quaker - Agroperina popofensis indela $(\mathrm{Sm}$.$) - \mathrm{s}$ Sask. $\mathrm{n}$ to Nipawin Provincial Park.

Muddy Quaker - Agroperina lutosa (And.) - Fort Qu'Appelle.

Yellow Three-spot - Agroperina helva (Grt.) - Roche Percee.

White-veined Quaker - Protagrotis niveivenosa (Grt.) - $\mathrm{s}$ Sask. $\mathrm{n}$ to Shoal Lake.

Dark White-veined Quaker - Protagrotis extensa (Sm.) - s Sask. $\mathrm{n}$ to Aylsham.

Destructive Quaker - Crymodes devastator (Brace) - s Sask. n to Love.

Mountain Quaker - Crymodes longula (Grt.) - Killdeer and Saskatchewan Landing Provincial Park.

Dock Rustic - Luperina passer (Gn.) - s Sask. $\mathrm{n}$ to Cumberland House.

Stipata Rustic - Luperina stipata (Morr.) - s Sask. $n$ to Regina.

Northern Banded Quaker - Trichoplexia 


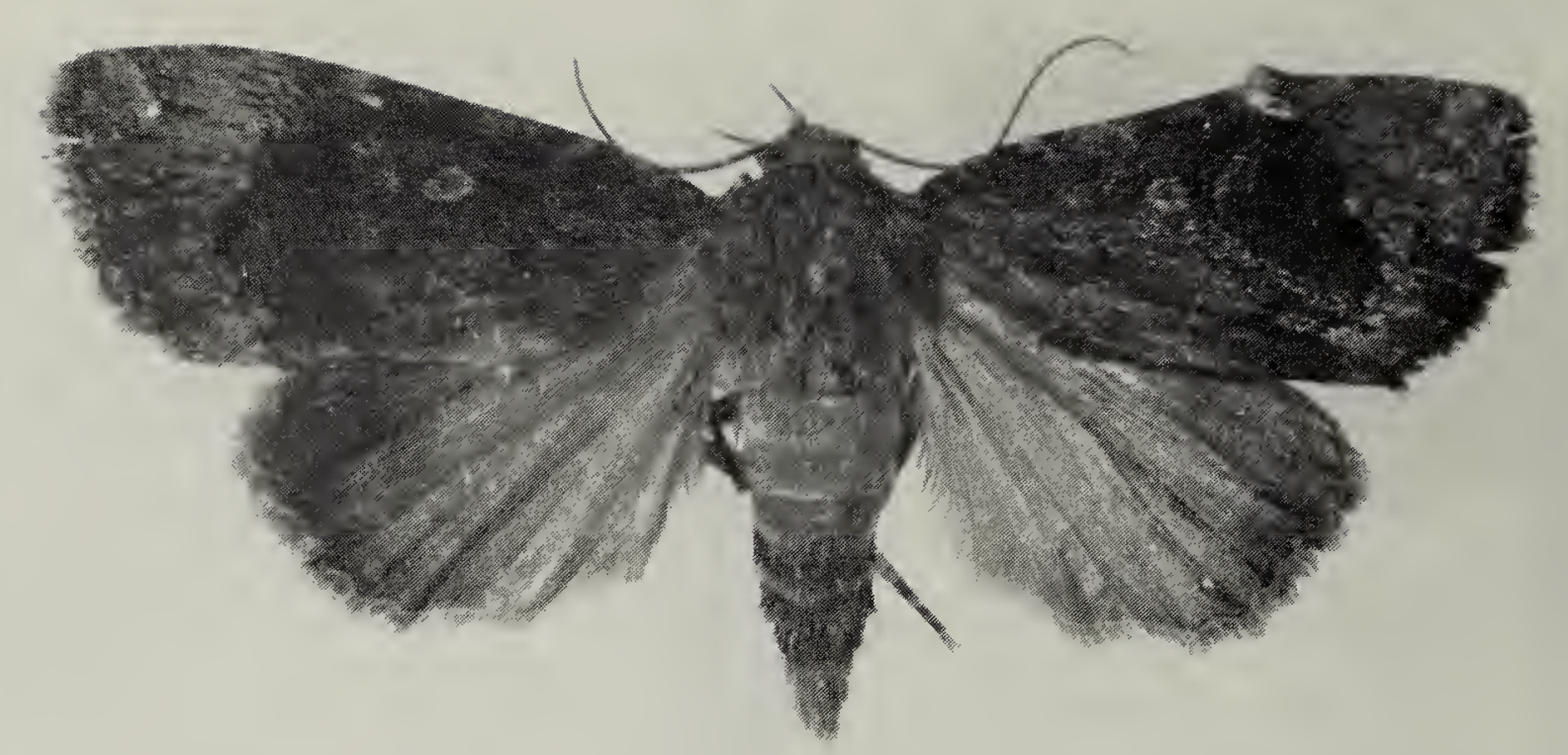

Copper Underwing

Lorie Melit

exornata (Mosch.) - Saskatoon (CNC).

Alberta Quaker - Eremobina claudens (Wlk.) - s Sask. n to Hudson Bay and Aylsham.

Black-banded Brocade - Oligia modica (Gn.) - s Sask. $\mathrm{n}$ to Tantallon and Saskatoon.

Lined Stalk-borer - Oligia fractilinea (Grt.) - s Sask. n to Aylsham.

Short-cloaked Quaker - Oligia tonsa (Grt.) - Fort Qu'Appelle and Loon Lake.

Bridgham's Brocade - Oligia bridghami (G. and R.) - s Sask. n to Shoal Lake.

Neumogen's Quaker - Oligia egens (Wlk.) - s Sask. n to Aylsham.

Obtuse Quaker - Oligia obtusa (Sm.) Shoal Lake and Saskatoon.

Prairie Quaker - Oligia mactata (Gn.) s Sask. $n$ to Shoal Lake and Meadow Lake Provincial Park.

Wandering Quaker - Oligia illocata (Wlk.) - s Sask. $\mathrm{n}$ to Shoal Lake and Prince Albert.

Mottled Quaker - Parastichtis discivaria (Wlk.) - s Sask. n to La Ronge.

Chagnon's Quaker - Xylomoia chagnoni (B. \& McD.) - Melfort and Saskatoon
Silver-C Borer - Spartiniphaga includens (Wlk.) - s Sask. n to Shoal Lake, Anglin Lake and Harlan (ne of Lloydminster).

Single-spot Borer - Spartiniphaga inops (Grt.) - Wadena and Aylsham.

Panatela Borer - Spartiniphaga panatela (Sm.) - Roche Percee and Duck Mountain Provincial Park.

Sordid Wainscot - Hypocoena inquin.ta (Gn.) - s Sask. n to Red Ear's. and Nipawin Provincial Park.

Base-streaked Wainscot - Hypocoena basistriga (McD.) - central Sask. $s$ to Norquay and Saskatoon, $\mathrm{n}$ to Shoal Lake.

Brown-streaked Rustic - Hypocoena rufostrigata (Pack.) - s Sask. n to Shoal Lake.

Narrow-winged Borer - Hypocoena defecta (Grt.) - s Sask. $n$ to La Ronge.

Oblong Sedge Borer Moth - Archanara oblonga (Grt.) - Saskatoon (CNC).

Suflava Sedge Borer - Archanara subflava (Grt.) - s Sask. n to Shoal Lake.

Kidney-spotted Rustic - Helotropha reniformis (Grt.) - s Sask. n to Shoal 
Lake and Prince Albert.

Interoceanic Ear Moth - Amphipoea interoceanica $(\mathrm{Sm}$.$) - \mathrm{s}$ Sask. $\mathrm{n}$ to Aylsham.

American Ear Moth - Amphipoea americana (Spey.) - s Sask. In to Shoal Lake and La Ronge.

Burdock Borer Moth - Papaipema cataphracta (Grt.) - Buffalo Pound Provincial Park.

Cow Parsnip Borer Moth - Papaipema harrisii (Grt.) - s Sask. n to Sturgeon Landing.

Columbine Borer - Papaipema leucostigma (Harr.) - Norquay and Limerick.

Hops Borer Moth - Papaipema circumlucens (Sm.) - Roche Percee, Oxbow and Fort Qu'Appelle.

Water Hemlock Borer Moth Papaipema marginidens (Gn.) - s Sask. $\mathrm{n}$ to Shoal Lake.

Meadow Rue Borer Moth - Papaipema unimoda (Sm.) - Melfort (CNC).

Pallid Rustic - Hydraecia pallescens (Sm.) - Ravenscrag (CNC).

Oblique Rustic - Hydraecia perobliqua (Hamp.) - s Sask. n to Shoal Lake.

Brown-tailed Diver - Bellura gortynoides (Wlk.) - Weekes.

Pale-shouldered Brindle - Bellura obliqua (Wlk.) - $\mathrm{s}$ Sask. $\mathrm{n}$ to Cumberland House and Onion Lake.

Charata Quaker - Aseptis charata (Grt.) - Killdeer, Val Marie, and Estuary.

American Small Angle Shades Euplexia benesimilis (McD.) - s Sask. $\mathrm{n}$ to Love.

Olive Angle Shades - Phlogophora iris (Gn.) - Bainbridge (n of Hudson Bay) and Bjorkdale.

Great Angle Shades - Phlogophora periculosa (Gn.) - Tantallon, Somme and Fort Qu'Appelle.

Angle-striped Sallow - Enargia decolor (Wlk.) - s Sask. n to Cumberland House and Meadow Lake Provincial Park.

Lesser Angle-striped Sallow - Enargia infumata (Grt.) - s Sask. $\mathrm{n}$ to Sturgeon Landing, and Gordon Lake ( $\mathrm{n}$ of Pinehouse Lake).

Mephisto Angle-striped Sallow Enargia mephisto (Franc.) - Harlan (ne of Lloydminster) (CNC).

Even-lined Sallow - Ipimorpha pleonectusa (Grt.) - s Sask. n to Gordon Lake (n of Pinehouse Lake).

Cloaked Marvel - Chytonix palliatricula (Gn.) - s Sask. n to Sturgeon Landing and La Ronge.

Canadian Giant - Andropolia contacta (Wlk.) - s Sask. n to La Ronge.

Hyppa - Hyppa (undescribed species) $\mathrm{s}$ Sask. $\mathrm{n}$ to Gordon Lake ( $\mathrm{n}$ of Pinehouse Lake).

Yellow Orange-wing - Pseudanarta crocea (Hy. Edw.) - Roche Percee and Killdeer.

Spotted Phosphila - Phosphila miselioides (Gn.) - Tantallon and Roche Percee.

Delicate Trachea - Trachea delicata (Grt.) - s Sask. n to Fort Esperance, Earl Grey and Outlook Regional Park.

Copper Underwing - Amphipyra pyramidoides $(\mathrm{Gn}$.$) - \mathrm{s}$ Sask. $\mathrm{n}$ to Shoal Lake and Red Earth.

Gray Amphipyra - Amphipyra glabella (Morr.) - s Sask. $n$ to Aylsham.

Glistening Rustic - Proxenus miranda (Grt.) - s Sask. $\mathrm{n}$ to Aylsham and Clearwater River.

Mooned Rustic - Platyperigia meralis (Morr.) - s Sask. n to Geikie River (near Wollaston Lake).

Civil Rustic - Platyperigia extima (Wlk.) - s Sask. n to Aylsham, Prince Albert and Battlefords Provincial Park.

White-blotched Balsa - Balsa labecula (Grt.) - Tantallon, Maryfield, Glen Ewen and Roche Percee.

Festive Midget - Elaphria festivoides 
(Gn.) - throughout Sask. (except ne corner).

White-dotted Groundling - Platysenta videns (Gn.) - s Sask. $\mathrm{n}$ to Wadena, Saskatoon and Cutknife.

Streaked Groundling - Platysenta discinstringa $(\mathrm{Sm}$.$) - Rockglen and \mathrm{Val}$ Marie.

Expallidus Brown - Plagimimcus expallidus (Grt.) - Saskatoon (Department of Agriculture collection, Saskatoon).

Yellow Groundling - Stiria rugifrons (Grt.) - Saskatoon and Swift Current (Department of Agriculture collection, Saskatoon).

American Dun-bar - Cosmia calami (Harv.) - Tantallon, Round Lake (s of Stockholm) and Oxbow.

Sharp-toothed Groundling - Acopa perpallida (Grt.) - Fort Qu'Appelle, Lumsden and Killdeer.

Homogena Groundling - Escaria homogena (McD.) - Saskatoon, Swift Current, Killdeer and Rosefield (se of Val Marie).

Cylindrical Groundling - Afotella cylindrica (Grt.) - Swift Current (CNC).

\section{Expected Species}

Wild Rice Quaker - Apamea apamiformis (GN.) - $\mathrm{w}$ to Aweme, Manitoba.

Western Quaker - Apamea occidens (Grt.) - n to Cartwright, Manitoba, and Manyberries, Alberta.

Burgess's Quaker - Crymodes burgessi (Morr.) - w to Fort Peck, Montana, and Writing-on-Stone Park, Alberta.

Jocasta Quaker - Eremobina jocasta (Sm.) - w to Winnipeg Beach, Manitoba, and Lamont, Alberta.

Verona Borer Moth - Papaipema verona (Sm.) - w to Aweme, Manitoba.

Ash Tip Borer Moth - Papaipema furcata $(\mathrm{Sm}$.) - w to Aweme, Manitoba.

Nelita Borer Moth - Papaipema nelita
(Stkr.) - w to Aweme, Manitoba.

Rigid Sunflower Borer Moth Papaipema rigida (Grt.) - w to Aweme, Manitoba.

Aweme Borer Moth - Papaipema aweme (Lym.) - Aweme, Manitoba.

American Bird's-wing Moth Dypterygia rozmani (Berio) - $\mathrm{w}$ to Aweme, Manitoba.

Subvexa Sallow - Ipimorpha subvexa (Grt.) - $\mathrm{n}$ to se Alberta.

Actona Sallow - Rhizagrotis albalis actona (Sm.) - $\mathrm{n}$ to Manyberries, Alberta.

White-winged Quaker - Protoperigia posticata (Harv.) - ne to Malta, Montana.

Verbena Moth - Crambodes talidiformis (Gn.) - nw to Medicine Hat, and Lethbridge, Alberta.

Fall Armyworm Moth - Spodoptera frugiperda (J.E. Smith) - nw to Aweme, Manitoba.

Frothy Moth - Stibadium spumosum (Grt.) - nw to $s$ Alberta. A pest in Sunflower heads.

\section{References}

BIRD, H. 1907. New histories and species in Papaipema (Hydroecia). Can. Ent. 39:309-317.

FORBES, W.T.M. 1954. Lepidoptera of New York and neighboring states. Noctuidae (Part III). New York State College of Agriculture, Ithaca, New York.

FRANCLEMONT, J.G. 1939. A revision of the American species of the genus Enargia Hubner. Can. Ent. 71:113-116.

KNUTSON, H. 1944. Minnesota Phalaenidae. University of Mimnesota Agricultural Experimental Station, Technical Bulletin 165.

LYMAN, H.H. 1908. Recent work among the Borers. Can. Ent. 40:249-255.

MCDUNNOUGH, J. 1922. Some apparently undescribed Noctuidae. Can. Ent. 54:236-238. 